Reviu Akuntansi dan Bisnis Indonesia, Vol. 2 No. 2, Hlm: 144-152, Desember 2018

Website: http://journal.umy.ac.id/index.php/rab

\title{
Pengaruh Kepemilikan Institusional, Free Cash Flow (FCF), dan Investment Opportunity Set (IOS) Terhadap Kebijakan Hutang (Studi Empiris pada Perusahaan Manufatur Yang Terdaftar di Bei Tahun 2014-2016)
}

\author{
Rika Nofiani; Barbara Gunawan \\ Program Studi Akuntansi Univeritas Muhammadiyah Yogyakarta.
}

\section{N F O A R T I K E L}

\section{Kata Kunci:}

Kepemilikan institusional, free cash flow (FCF), investment opportunity set (IOS), Kebijakan Hutang.

Jenis Artikel:

Penelitian Empiris

Correspondence: era@umy.ac.id

\author{
A B S T R A K
}

Penelitian ini bertujuan untuk menguji pengaruh kepemilikan institusional, arus kas bebas (FCF), dan set kesempatan investasi (IOS) pada kebijakan hutang perusahaan manufaktur yang terdaftar di Bursa Efek Indonesia (BEI) pada tahun 2014-2016. Teknik pengambilan sampel yang digunakan adalah purposive sampling dengan 108 sampel setelah dikurangi dari outlier. Metode analisis yang digunakan adalah analisis regresi linier berganda. Hasil penelitian menunjukkan bahwa kepemilikan institusional dan set kesempatan investasi (IOS) tidak berpengaruh pada kebijakan hutang. Sedangkan arus kas bebas (FCF) berpengaruh positif terhadap kebijakan utang.

(C) 2019 RAB. Published by Universitas Muhammadiyah Yogyakarta

\section{PENDAHULUAN}

Masalah dana usaha adalah masalah serius bagi setiap pengusaha di dunia. Tidak ada seorangpun yang akan bisa maju tanpa ada dana usaha yang cukup (Gunawan, 2001). Berbagai sumber dana perusahaan membutuhan pengelolaan dana untuk bisa memenuhi sumber dana yang sesuai. Setiap keputusan sumber dana perusahaan memiliki perbedaan karakteristik dan konsekuensi keuangan (Sudiyatno dan Sari, 2013). Dana sendiri, dana modal saham atau hutang biasanya merupakan sumber pemenuhan dana. Hutang yang akan dipergunakan diputuskan melalui kebijakan hutang (Safitri dan Asyik, 2015).

Data Bank Indonesia (BI) tahun 2015 menunjukkan hutang luar negeri (LN) pemerintah semakin menimbulkan kekhawatiran. Selain itu hutang luar negeri swasta (LNS) juga menimbulkan kecemasan. Akhir bulan Desember tahun 2014 berjumlah US \$162,8 miliar, dan pada kuartal I tahun 2015 berjumlah US $\$ 165,3$ miliar (Satrio, 2015). Hal tersebut menunjukkan fakta mayoritas perusahaan yang berada di Indonesia masih memiliki hutang cukup besar dan membahayakan. Oleh karena itu diharapkan dengan adanya kebijkan hutang akan mampu meminimalisir hutang perusahaan yang ada di Indonesia.

Kebijakan hutang adalah kebijakan dana dalam perusahaan yang dipergunakan untuk mendanai kegiatan operasional perusahaan. Kebijakan hutang tersebut akan menentukan kemampuan perusahaan dalam menjalankan bisnis yang dilakukan. Ada berbagai faktor yang mempengaruhi kebijakan hutang yaitu kepemilikan institusional, free cash flow (FCF), dan investment opportunity set (IOS). 
Penelitian ini bisa memberikan informasi dan kebijakan untuk pimpinan dan pemerintah, pengambilan keputusan yang strategis dengan memahami faktor-faktor yang berpengaruh positif maupun negatif dalam periode tertentu. Penelitin ini merupakan replikasi penelitian terdahulu yang sudah dilakukan Safitri dan Asyik (2015) berkaitan dengan kepemilikan institusional dan free cash flow terhadap kebijakan hutang. Perbedaan dengan penelitian sebelumnya yaitu dengan menambah satu variabel independen invesment opportunity set (IOS) dan tahun penelitian yang diuji. Berdasarkan permasalahan diatas, maka penelitian ini memiliki tujuan untuk menguji dan memperoleh bukti empiris tentang pengaruh kepemilikan institusional, Free Cash Flow (FCF) dan Investment Opportunity Set (IOS) terhadap kebijakan hutang pada perusahaan manufaktur yang terdaftar di BEI periode tahun 2014-2016.

\section{TINJAUAN LITERATUR DAN PERUMUSAN HIPOTESIS}

\section{Teori Keagenan}

Teori keagenan menguraikan tentang adanya hubungan keagenan diantara manajemen (agen) dengan investor (prinsipal). Jensen dan Meckling (1976) menjelaskan teori keagenan merupakan sebuah kontrak antara agen dengan prinsipal. Teori keagenen adalah hubungan yang berlangsung pada saat satu atau lebih orang, yaitu manajemen yang membutuhkan seseorang atau organisasi lain (investor) untuk melimpahkan wewenang dalam melakukan keputusan kepada manajemen tersebut (Brigham dan Houston, 2010). Safitri dan Asyik (2015) mengungkapkan hubungan keagenan yang mendasar terjadi antara pemegang saham dan manager kemudian antara manager dan pemilik hutang.

\section{Kebijakan Hutang}

Kebijakan hutang juga merupakan semua macam hutang yang diciptakan atau dibuat perusahaan, mulai dari hutang jangka panjang dan hutang jangka pendek (Indahningrum dan Handayani, 2013). Perusahaan dengan pertumbuhan tingkat rendah yang memiliki tingkat kemampuan untuk memperoleh laba yang rendah menyebabkan penggunaan hutang untuk mendanai perusahaan akan meningkat (Mahsunah dan Hermanto, 2013).

\section{Free Cash Flow (FCF)}

Free cash flow adalah kas berlebih perusahaan yang tidak dibutuhkan kembali untuk penenaman modal pada aset tetap dan bisa dialokasikan kepada pemegang saham (Tarjo dan Jogiyanto, 2003). Free cash flow merupakan kas berlebih pada perusahaan, yang dibutuhkan untuk mendanai semua kegiatan yang mempunyai net present value (NPV) positif sesudah dibagi deviden (Sonjaya, 2015).

\section{Investment Opportunity Set (IOS)}

Arieska dan Gunawan (2011) menjelaskan investment opportunity set merupakan adanya pilihan lain penanaman modal bagi perusahaan pada masa mendatang. Myers (1983) menjelaskan sebuah konsep tentang set kesempatan investasi, Pada mulanya investment opportunity set (IOS) merupakan gabungan aktiva riil yang dimiliki yang sifatnya berwujud dengan kesempatan investasi yang sifatnya tidak berwujud.

\section{Kepemilikan Institusional dan Kebijakan Hutang}

Crutchley dan Hansen (1989) mengemukakan kepemilikan institusional semakin tinggi, pengawasan dari luar kepada perusahaan semakin kuat pula. Beberapa hasil penelitian terdahulu 
yaitu Indahningrum dan Handayani (2013) diketahui variabel kepemilikan institusional memiliki pengaruh dengan arah positif serta signifikan dengan kebijakan hutang. Bernice (2015) dan Nabela (2012) juga diketahui bahwa kepemilikian institusional memiliki pengaruh arah positif dengan kebijakan hutang. Hal tersebut diketahui bahwa kepemilikan institusional yang semakin tinggi, maka semakin efektif adanya prinsipal institusional dalam mengawasi perilaku dalam manajemen. Hasil penelitian Fitriyah dan Hidayat (2011), Susilawati (2010), dan Trisnawati (2016) diketaui kepemilikan institusional memiliki pengaruh dengan kebijakan hutang. Berkaitan dengan struktur kepemilikan dalam perusahaan kepemilikan institusional memiliki pengaruh yang besar dalam menentukan keputusan pendanaan. Hal ini dikarenakan pemilik institusional mempunyai kepemilikan atas saham yang lebih besar dalam perusahaan, sehingga pemilik institusional dapat ikut menentukan keputusan pendanaan terkait kebijakan hutang yang dapat diambil oleh manajer, yaitu:

\section{$\boldsymbol{H}_{\boldsymbol{I}}$ : Kepemilikan institusional berpengaruh positif terhadap kebijakan hutang.}

\section{Free Cash Flow dan Kebijakan Hutang}

Kallapur dan Trombley (1999) mengemukakan free cash flow adalah cash yang berasal dari aktivitas perusahaan, dan kas tersebut tidak diperlukan untuk membiayai pekerjaan-pekerjaan yang memiliki net present value (NPV) positif. Indahningrum dan Handayani (2013), Susilawati (2010) dan Syafi'i (2011), serta Setiana dan Sibagariang (2013), melakukan penelitian dengan hasil free cash flow (FCF) memiliki pengaruh dengan arah positif terhadap kebijakan hutang, dan semakin banyak free cash flow yang dimiliki perusahaan menyebabkan semakin tinggi kebijakan hutang. Pada penelitian ini juga didukung oleh Ariyanti (2013), dan Mahsunah dan Hermanto (2013) yang membuktikan bahwa FCF memiliki pengaruh signifikan terhadap kebijakan hutang.

Free cash flow menggambarkan keleluasaan perusahaan dalam membeli saham, menambah likuiditas, membayarkan hutang, serta melakukan investasi tambahan bagi perusahaan. Free cash flow yang semakin besar maka kesanggupan perusahaan dalam membayarkan hutangnya juga semakin besar, sehingga ketika perusahan memiliki free cash flow yang memadai maka kebijakan hutang dapat diabil oleh pihak manajer perusahaan. Free cash flow yang semakin tinggi maka semakin tinggi pula kebijakan hutang perusahaan. Berdasarkan penjelasan tersebut, peneliti mengajukan hipotesis yaitu sebagai berikut:

\section{$\boldsymbol{H}_{\boldsymbol{z}}$ : Free cash flow berpengaruh positif terhadap kebijakan hutang.}

\section{Investment Opportunity Set (IOS) dan Kebijakan Hutang}

Investment opportunity set (IOS) merupakan kombinasi aktiva riil yang dimiliki yang bersifat berwujud dengan peluang investasi atau pilihan pertumbuhan yang sifatnya tidak berwujud (Myers, 1983). Hasil penelitian yang dilakukan Fitriyah dan Hidayat (2011), dan Putri dan Chabachib (2013) diketahui set kesempatan investasi memiliki pengaruh signifikan dengan arah negatif terhadap kebijakan hutang. Semakin tinggi IOS dapat menyebabkan kebijakan hutang menjadi semakin rendah. Hasil penelitian Yanuar (2012), Nurhaida (2014) dan Linda dkk (2017) diketahui investment opportunity set memiliki pengaruh dengan kebijakan hutang.

Peluang pertumbuhan perusahaan terlihat pada peluang investasi. Perusahaan yang memiliki peluang investasi atau peluang pertumbuhan yang tinggi, lebih cenderung menggunakan sumber pendanaan internal untuk mendanai aktivitas operasional perusahaan daripada harus melakukan pinjamam atau hutang yang mengandung risiko. Risiko tersebut berkaitan dengan ketidakmampuan perusahaan dalam membayar hutangnya. Berdasarkan penjelasan tersebut, maka peneliti mengajukan hipotesis yaitu sebagai berikut: 
$\boldsymbol{H}_{s}$ : Investment opportunity set berpengaruh negatif terhadap kebijakan hutang.

\section{METODE PENELITIAN}

Objek penelitian yaitu data kepemilikan institusional, free cash flow, investment opportunity set dan kebijakan hutang tahun 2014-2016 pada perusahaan manufaktur BEI. Jenis data penelitian ini yaitu data sekunder berupa kumpulan angka-angka dari kepemilikan institusional, free cash flow (FCF), investment opportunity set (IOS) serta kebijakan hutang. Teknik pengambilan sampel penelitian ini menggunakan metode purposive sampling yaitu merupakan sampel yang ditentukan berdasarkan kriteria pemilihan sampel yang telah ditentukan. Adapun kriteria perusahaan yang dijadikan sampel sebagai berikut:

1. Perusahaan manufaktur yang terdaftar di Bursa Efek Indonesia (BEI) terus menerus selama tahun 2014-2016.

2. Perusahaan yang menggunakan satuan mata uang rupiah dalam laporan keuangan.

3. Perusahaan yang mempunyai data kepemilikan institusional, free cash flow (FCF), investment opportunity set (IOS) dan kebijakan hutang selama tahun 2014-2016.

Teknik pengumpulan data menggunakan metode dokumentasi. Analisis statistik dengan program SPSS versi 24.0. Regresi berganda merupakan teknik analisa statistik yang dipergunakan untuk mengukur besarnya pengaruh variabel independen dan variabel dependen. Persamaan regresi pada peneltian ini dirumuskan menjadi suatu model persamaan, sebagaimana hipotesis dan model kerangka penelitian. Persamaan regresi diformulasikan sebagai berikut.

$$
\mathrm{KHU}=\alpha+\beta_{1} \mathrm{INS}_{1}+\beta_{2} \mathrm{FCF}_{2}+\beta_{3} \mathrm{MVE}_{3}+\mathrm{e}
$$

Keterangan:

$$
\begin{array}{ll}
\mathrm{A} & =\text { Konstanta } \\
\beta_{1-3} & =\text { Koefisien Regresi } \\
\mathrm{INS}_{1} & =\text { Kepemilikan institusi } \\
\mathrm{FCF}_{2} & =\text { Free Cash Flow } \\
\mathrm{MVE}_{3} & =\text { Insvestment Opportunity Set } \\
\text { KHU } & =\text { Kebijakan Hutang } \\
\mathrm{e} & =\text { error }
\end{array}
$$

\section{HASIL DAN PEMBAHASAN}

\section{Uji Normalitas}

Tabel 1 Hasil Uji Normalitas

\begin{tabular}{cccc}
\hline Variabel & KSZ & Sig. & Keterangan \\
\hline Unstandardized Residual & 1,179 & 0,124 & Normal \\
\hline
\end{tabular}

Tampak pada Tabel 1 nilai Kolmogorov-Smirnov pada variabel penelitian, dengan nilai signifikansi lebih besar dari 0,05 sehingga dapat dikatakan berdistribusi normal.

\section{Uji Multikolinieritas}


Tabel 1.2 Hasil Uji Multikolinieritas

\begin{tabular}{|c|c|c|c|}
\hline Variabel & Tolerance & $V I F$ & Keterangan \\
\hline INS & 0,829 & 1,206 & No multikolinieritas \\
\hline $\mathrm{FCF}$ & 0,943 & 1,061 & No multikolinieritas \\
\hline IOS & 0,863 & 1,159 & No multikolinieritas \\
\hline
\end{tabular}

Tampak pada Tabel 1.2 bahwa hasil uji multikolineritas masing-masing variabel independen diperoleh Tolerance $>0,1$ dan nilai $V I F<10$ nilai maka dapat disimpulkan bahwa tidak terjadi gejala multikolinearitas.

\section{Uji Autokorelasi}

Tabel 1.3 Hasil Uji Autokorelasi

\begin{tabular}{ccccc}
\hline $\begin{array}{c}\text { Jumlah Variabel } \\
\text { Bebas }\end{array}$ & DU & 4-DU & Nilai Durbin Watson & Keputusan \\
\hline 3 & 1,604 & 2,396 & 1,754 & $\begin{array}{c}\text { Tidak terjadi } \\
\text { autokorelasi }\end{array}$ \\
\hline
\end{tabular}

Tampak pada Tabel 1.3 bahwa hasil uji autokorelasi menunjukkan bahwa nilai du $<$ DW $<$ (4-du) atau $1,604<1,754<2,396$ artinya model regresi bebas dari masalah autokorelasi atau tidak ada autokorelasi antara kesalahan penggangu.

Uji Heteroskedastisitas

Tabel 1.4 Hasil Uji Heteroskedastisitas

\begin{tabular}{cccc}
\hline Variabel & $\boldsymbol{T}_{\text {hims }}$ & Sig. & keterangan \\
\hline INS & $-1,318$ & 0,190 & $\begin{array}{c}\text { Tidak terjadi } \\
\text { heteroskedastisitas } \\
\text { Tidak terjadi } \\
\text { FCF }\end{array}$ \\
heteroskedastisitas \\
Tidak terjadi \\
IOS & 0,807 & 0,421 & heteroskedastisitas \\
\hline
\end{tabular}

Tampak pada Tabel 1.4 heteroskedasitas dengan metode glejser, jika hasil analisis absolut variabel independen tidak signifikan secara statistik tidak berpengaruh terhadap variabel terikat maka tidak terjadi Heteroskedasitas, menunjukkan bahwa nilai signifikan masing-masing variabel independen (signifikansi > 0,05) sehingga dikatakan tidak terjadi heteroskedastisitas.

\section{Analisis Regresi Berganda}

Tabel 1.5 Hasil Uji Regresi Linear Ganda

\begin{tabular}{|c|c|c|c|}
\hline Variabel & $\begin{array}{c}\text { Unstandardized } \\
\text { Coefficients }\end{array}$ & Sig. & Keterangan \\
\hline INS & 0,401 & 0,240 & Ditolak \\
\hline FCF & 0,867 & $0,030^{*}$ & Diterima \\
\hline IOS & 0,055 & 0,392 & Ditolak \\
\hline Konstanta & \multicolumn{2}{|c|}{0,650} & \\
\hline$F_{\text {himus }}$ & \multicolumn{2}{|c|}{3,166} & \\
\hline Sig. F & \multicolumn{2}{|c|}{0,028} & \\
\hline$R$ Square & \multicolumn{2}{|c|}{0,057} & \\
\hline Variabel dependen & \multicolumn{2}{|c|}{ KHU (Kebijakan Hutang) } & \\
\hline
\end{tabular}

${ }^{*}$ Nilai signifikan $<5 \%$ 
Hasil analisis regresi berganda tampak pada Tabel 4.7 dapat diperoleh persamaan regresi sebagai berikut:

$$
\text { Kebijakan Hutang }=0,650+0,401 \mathrm{INS}+0,867 \mathrm{FCF}+0,055 \mathrm{IOS}+\mathrm{e}
$$

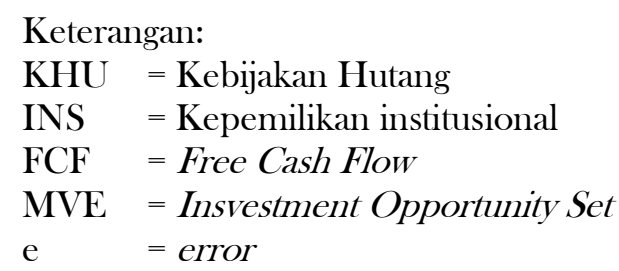

\section{Koefisien Determinasi (Adjusted $\left.R^{2}\right)$}

Tabel 1.6 Hasil Uji Koefisien Determinasi

\begin{tabular}{ccccc}
\hline Model & R & R Square & $\begin{array}{c}\text { Adjusted R } \\
\text { Square }\end{array}$ & Std. Error of the Estimate \\
\hline 1 & 0,289 & 0,084 & 0,057 & 0,88664 \\
\hline
\end{tabular}

Tampak pada Tabel 1.6 nilai adjusted $\boldsymbol{R}$ swuare adalah sebesar 0,057 atau 5,7\%. Hal ini menunjukkan bahwa kemampuan variabel bebas yaitu kepemilikan institusioanal, free cash flow (FCF) dan investment opportunity set (IOS) dapat menjelaskan variabel terikat sebesar 5,7\% sedangkan sisanya dijelaskan faktor lain yang tidak terdapat dalam penelitian ini.

\section{Pengujian hipotesis (uji nilai t)}

Tabel 1.7 Hasil Uji Nilai t Statistik

\begin{tabular}{lccl}
\hline \multicolumn{1}{c}{ Variabel } & Koefisioen Regresi & Sig.t & \multicolumn{1}{c}{ Keterangan } \\
\hline INS & 0,401 & 0,240 & Ditolak \\
FCF & 0,867 & 0,030 & Diterima \\
IOS & 0,055 & 0,392 & Ditolak \\
Variabel dependen $:$ KHU & & &
\end{tabular}

\section{Pengaruh Kepemilikan Institusional terhadap Kebijakan hutang}

Berdasarkan hasil uji hipotesis yang tampak pada Tabel 1.7 dapat diketahui bahwa variabel kepemilikan institusional tidak berpengaruh terhadap kebijakan hutang dibuktikan dengan nilai koefisien regresi sebesar 0,401 yang memiliki arah positif dengan tingkat signifikansi sebesar 0,240 $>\alpha(0,05)$, hasil ini tidak sesuai dengan hipotesis yang diajukan sehingga hipotesis pertama ditolak. Hasil penelitian yang dilakukan sejalan dengan penelitian yang dilakukan oleh Safitri dan Asyik (2015), Ariyanti (2013), Murtiningtyas (2012), serta Setiana dan Sibagariang (2013) yang menyatakan bahwa variabel kepemilikan institusional tidak berpengaruh terhadap kebijakan hutang. Namun hasil penelitian ini tidak sejalan dengan penelitian yang dilakukan oleh Yeniatie dan Destriana (2010), Indahningrum dan Handayani (2013), serta Bernice (2015) yang menyatakan bahwa variabel kepemilikan institusional berpengaruh terhadap kebijakan hutang. Hal tersebut dikarenakan kepemilikan institusional berlaku sebagai pengawas terhadap kinerja manajemen.

Kepemilikan institusional merupakan perihal kepemilikan saham yang dimiliki suatu lembaga maupun instansi perusahaan seperti bank, investasi, asuransi, dan institusi lainnya. Pembagian saham antara stakeholder dari luar seperti investor institusional bisa mengurangi anggaran agensi (Wahidahwati, 2002). Besar kecilnya kepemilikan institusional tidak akan berpengaruh terhadap pengambilan keputusan kebijakan hutang, karena Manajer merupakan pengelola perusahaan yang lebih mengetahui keadaan perusahaan sehingga dalam menentukan hutang akan mempertimbangkan segala risiko atas penggunaan hutang sebagai pendanaan dengan 
mempertimbangkan faktor lain secara internal maupun eksternal untuk memenuhi kebutuhan perusahaan yang akan digunakan untuk menentukan berapa besar hutang yang akan diambil (Safitri dan Asyik, 2015).

\section{Pengaruh Free Cash Flow (FCF) terhadap Kebijakan hutang}

Berdasarkan hasil uji hipotesis yang tampak pada Tabel 1.7 dapat diketahui bahwa variabel Free Cash Flow berpengaruh positif dan signifikan terhadap kebijakan hutang dibuktikan dengan nilai koefisien regresi sebesar 0,867 yang memiliki arah positif dengan tingkat signifikansi sebesar $0,030<\alpha(0,05)$, hasil ini sesuai dengan hipotesis yang diajukan yaitu Free Cash Flow berpengaruh positif terhadap kebijakan hutang sehingga hipotesis kedua diterima. Hasil penelitian yang dilakukan sejalan dengan penelitian yang dilakukan oleh Setiana dan Sibagariang (2013), Indahningrum dan Handayani (2013), Ariyanti (2013), Syafi'i (2011) yang menyatakan bahwa variabel Free Cash Flow berpengaruh positif terhadap kebijakan hutang.

Namun hasil penelitian ini tidak sejalan dengan penelitian yang dilakukan Trisnawati (2016) yang menyatakan bahwa variabel Free cash flow tidak berpengaruh terhadap kebijakan hutang. Free cash flow merupakan kas berlebih pada perusahaan, yang dibutuhkan untuk mendanai semua kegiatan yang mempunyai NPV positif sesudah dibagi deviden (Sonjaya, 2015). Cash flow merupakan adanya dana berlebihan, yang semestinya dialokasikan pada pemegang saham. Free cash flow menggambarkan kebebasan perusahaan untuk melakukan penanaman modal tambahan, menambah likuiditas, membeli saham dan melunasi hutang (Arieska dan Gunawan, 2011).

\section{Pengaruh Investment Opportunity Set (IOS) Terhadap Kebijakan Hutang}

Berdasarkan hasil uji hipotesis yang tampak pada Tabel 1.7 dapat diketahui bahwa variabel investment opportunity set tidak berpengaruh terhadap kebijakan hutang dibuktikan dengan nilai koefisien regresi sebesar 0,055 yang memiliki arah positif dengan tingkat signifikansi sebesar 0,392 $>\alpha(0,05)$, hasil ini tidak sesuai dengan hipotesis yang diajukan sehingga hipotesis ketiga ditolak. Hal ini disesabkan karena investment opportunity set bagi perusahaan sudah cukup serta berfungsi untuk meningkatkan produktivitas perusahaan, karena sumber dana perusahaan dapat dicukupi dengan besarnya investment opportunity set yang dilakukan perusahaan, sehingga dengan menggunakan sumber pendanaan internal untuk kegiatan operasional perusahaan lebih menguntungkan.

Dalam melakukan suatu investasi mungkin saja perusahaan sebelumnya sudah memprediksi atau sudah menyiapkan dana serta modal untuk melakukan investasi. Maka tinggi rendahnya investment opportunity set tidak akan berpengaruh terhadap pengambilan keputusan kebijakan hutang. Investment opportunity set juga merupakan karateristik yang digunakan perusahaan dalam menentukan cara pandang manajer, pemilik, investor, maupun kreditor terhadap keputusan pendanaan. Sehingga dapat disimpulkan bahwa tinggi rendahnya investment opportunity set tidak akan menentukan apakah kebijakan hutang perusahaan akan tinggi atau rendah (Andriella, 2015).

\section{KETERBATASAN PENELITIAN}

Penelitian yang dilakukan tidak terlepas dari keterbatasan, adapun beberapa keterbatasan penelitian antara lain penelitian ini hanya mengambil sampel dari perusahaan manufaktur sehingga belum dapat mencerminkan semua sektor perusahaan. Sampel dalam penelitian ini menggunakan periode pengamatan yang pendek, yaitu hanya 3 tahun sehingga kurang luas jangkauan periode pengamatannya. Hasil pengolahan data masih menunjukkan ada beberapa variabel yang tidak berdistribusi normal, sehingga beberapa sampel outlier yang harus dibuang. Penelitian ini hanya menggunakan tiga variabel independen, sedangkan masih ada variabel-variabel independen lain yang berpengaruh terhadap kebijakan hutang. 


\section{KESIMPULAN}

Penelitian ini bertujuan untuk menguji dan memperoleh bukri empiris tentang pengaruh kepemilikan institusional, Free Cash Flow (FCF), Investment Opportunity Set (IOS) terhadap kebijakan hutang pada perusahaan non keuangan yang terdaftar di Bursa Efek Indonesia (BEI) selama periode 2014-2016. Berdasarkan pengujian yang telah dilakukan dapat disimpulkan koefisien regresi kepemilikan institusional sebesar 0,401 yang memiliki arah positif dengan tingkat signifikansi sebesar $0,240>\alpha(0,05)$ sehingga $\mathrm{H}_{1}$ ditolak. Hasil ini tidak mendukung hipotesis pertama yang diajukan dalam penelitian ini. Sehingga dapat disimpulkan bahwa kepemilikan institusional tidak berpengaruh terhadap kebijakan hutang. Koefisien regresi free cash flow sebesar 0,867 yang memiliki arah positif dengan tingkat signifikansi sebesar $0,030<\alpha(0,05)$ sehingga $\mathrm{H}_{2}$ diterima. Hasil ini mendukung hipotesis pertama yang diajukan dalam penelitian ini. Sehingga dapat disimpulkan bahwa free cash flow berpengaruh positif dan signifikan terhadap kebijakan hutang. Koefisien regresi investment opportunity set sebesar 0,055 yang memiliki arah positif dengan tingkat signifikansi sebesar $0,392>\alpha(0,05)$ sehingga $\mathrm{H}_{3}$ ditolak. Hasil ini tidak mendukung hipotesis ketiga yang diajukan dalam penelitian ini. Sehingga dapat disimpulkan bahwa investment opportunity set tidak berpengaruh terhadap kebijakan hutang.

Berdasarkan hasil penelitian yang telah dilakukan dan kesimpulan yang telah dijelaskan diatas, maka dapat diajukan beberapa saran yang dapat dijadikan pertimbangan untuk penelitian selanjutnya diharapkan penelitian selanjutnya memperluas jumlah sampel dengan menambahkan perusahaan dari berbagai sektor dan periode pengamatan yang lebih panjang. Dalam penelitian selanjutnya sebaiknya menambahkan variabel atau faktor lain yang berpengaruh terhadap kebijakan hutang, tidak hanya sebatas variabel kepemilikan institusional, free cash flow, dan investment opportunity set. Beberapa variabel pada penelitian ini yang tidak terbukti sebaiknya pada penelitian selanjutnya digunakan proksi atau metode pengukuran yang lain dari variabel tersebut, sehingga diharapkan dapat mencerminkan variabel yang digunakan. Dalam penelitian selanjutnya dapat menggunakan variabel eksternal yang berpengaruh terhadap kebijakan hutang, seperti tingkat suku bunga atau tax rate.

\section{DAFTAR PUSTAKA}

Arieska, M \& Gunawan, B. (2011). Pengaruh Aliran Kas Bebas dan Keputusan Pendanaan terhadap Nilai Pemegang Saham dengan Set Kesempatan Investasi Deviden sebagai Variabel Moderasi. Jurnal Akuntansi dan Keuangan, 13 (1), 13-23.

Ariyanti, P.S. (2013). Insider Ownership, Deviden dan Kebijakan Hutang: Peran Moderasi Free Cash Flow. Jurnal Riset Akuntansi Keuangan, 9 (1), 69-91.

Bernice, Y. (2015). The Impact of Managerial Ownership, Institutional Ownership and Company Size towards Debt Policy. Journal International Conference and Bussines Economics and Accounting.

Brigham, E. F. \& Houston, J. F. (2010). Fundamental of Financial Management. Edisi Kesepuluh. Buku 1. South-Weastern. Singapore. Terjemahan A.A Yulianto. 2012. Dasar-dasar Managemen Keuangan. Edisi Kesepuluh. Buku 1. Jakarta: Salemba Empat.

Crutchley \& Hansen. (1989). A Test of Agency Theory of Managerial Ownership. Corporate Leverage and Corporate Dividends. Financial Management. 18.

Fitriyah, F.K \& Hidayat, D. (2011). Pengaruh Kepemilikan Institusional, Set Kesempatan Investasi dan Arus Kas Bebas terhadap Utang. Jurnal Media Riset Akuntansi, 1(1), 31-41.

Gunawan, B. (2001). Anjak Piutang: Sebuah Alternatif Memperoleh Dana Usaha. Jurnal Akuntansi dan Investasi, 2(2), 137-146.

Indahningrum \& Handayani. (2013). Pengaruh Kepemilikan Manajerial, Kepemilikan Institusional, Deviden, Pertumbuhan Perusahaan, Free Cash Flow, dan Profitabilitas terhadap Kebijakan Hutang Perusahaan. Jurnal Bisnis dan Akuntansi, 11(3), 189-207. 
Jensen, M. C \& Meckling, W.H. (1976). Theory of the Firm: Managerial Behavior, Agency Costs and Ownership Structure. Journal of Financial Economics, 3(4), 305-360.

Kallapur, S., \& Trombley, M. A. (1999). The Association Between Investment Opportunity Set Proxies and Realized Growth. Journal of Business Finance and Accounting.

Linda, Lautania M.F \& Arfandynata M. (2017). Determinan Kebijakan Hutang: Bukti Empiris pada Perusahaan yang Terdaftar di Bursa Efek Indonesia. Jurnal Dinamika Akuntansi dan Bisnis. Vol. 4(1), 91-112.

Mahsunah, T. \& Hermanto, S.B. (2013). Pengaruh free Cash Flow, Profitabilitas dan Kepemilikan Institusional terhadap Kebijakan Hutang. Jurnal Ilmu \& Riset Akuntansi, 2(12), 1-19.

Myers, S. (1983). The Capital Structure Puzzle. Journal of Finance, 39, 575- 592.

Nabela, Y. (2012). Pengaruh Kepemilikan Institusional, Kebijakan Deviden dan Profitabilitas terhadap Kebijakan Hutang pada Perusahaan Properti dan Real Estate di Bursa Efek Indonesia. Jurnal Manajemen, 1(1).

Nurhaida. (2014). Pengaruh Kepemilikan Manajerial, Profitabilita, dan Set Peluang Investasi terhadap Kebijakan Utang (Studi pada Perusahaan Manufaktur yang Terdaftar Di Bursa Efek Indonesia Tahun 2009-2011). Jurnal. Universitas Syiah Kuala, Banda Aceh.

Putri G.A.P \& Chabachib, M. (2013). Analisis Pengaruh Kepemilikan Institusional, Free Cash Flow, Investment Opportunity Set terhadap nilai Perusahaan dengan Kebijakan Hutang sebagai Variabel Intervening. Diakses di http://eprints.undip.ac.id/39017/1/PUTRI.pdf, tanggal 4 Mei 2017, pukul 12.30 WIB.

Safitri, I. \& Asyik. (2015). Pengaruh Kepemilikan Institusional dan Free Cash Flow terhadap Kebijakan Hutang. Jurnal Ilmu dan Riset Akuntansi. 4(7), 1-18.

Satrio. (2015). Utang Kita Sudah Berbahaya. Diakses di http://indonesianreview.com/satrio/utangkita-sudah-berbahaya, pada tanggal 4 Mei 2017, Pukul 11.00 WIB

Setiana, E \& Sibagariang, R. (2013). Pengaruh Free Cash Flow dan Kepemilikan Manajerial teradap Kebijakan Hutang pada Perusahaan Manufaktur yang Terdaftar di Bursa Efek Indonesia (BEI). Jurnal Telaah Akuntansi, 15(1), 16-33.

Sonjaya, Y. (2015). Analisis Pengaruh Free Cash Flow, Kebijakan Deviden, Kepemilikan Saham Manajerial, dan Kepemilikan Saham Institusional terhadap Nilai Perusahaan.

Sudiyatno, B \& Sari, S.M. (2013). Determinants of Debt Policy: An Empirical Studying Indonesia Stock Echange. Educational Research, 4(1), 141-5161.

Susilawati, R.A.E. (2010). Analisis Free Cash Flow dan Kepemilikan Manajerial terhdap Kebijakan Hutang pada Perusahaan Publik di Indonesia. Jurnal Ekonomi Modernisasi, 6(2), 109-129.

Syafi'i, I. (2011). Manajerial Ownership, Free Cash Flow dan Growth Opportunity Terhadap Kebijakan Hutang. Jurnal Media Mahardika, 1(1), 1-21.

Tarjo. \& Jogiyanto. 2003. Analisis Free Cash Flow dan Kepemilikan Manajerial terhadap Kebijakan Utang pada Perusahaan Publik di Indonesia, Simposium Nasional Akuntansi VI, Surabaya.

Tarjo. (2005). Analisa Free Cash Flow dan Kepemilikan Manajerial Terhadap Kebijakan Utang pada Perusahaan Publik di Indonesia. The Indonesian Journal of Accounting Research, 8(1).

Trisnawati, I. (2016). Faktor-Faktor yang Mempengaruhi Kebijakan Hutang pada Perusahaan NonKeuangan yang Terdaftar di Bursa Efek Indonesia. Jurnal Bisnis dan Akuntansi, 18(1), 3342.

Yanuar. (2012). Pengaruh Free Cash Flow, Set Kesempatan Investasi dan Ukuran Perusahaan terhadap Kebijakan Hutang Perusahaan. Jurnal. Universitas Gadjah Mada. 